\section{Root and Shoot Growth of Eucalyptus in Response to Container Configuration and Copper Carbonate}

\author{
U.K. Schuch and D.R. Pittenger \\ Botany and Plant Sciences Department, University of California, Riverside, \\ CA 92521
}

\begin{abstract}
Modifying container design by changing the height: width ratio of containers or coating the interior surface of containers with copper compounds are among the various strategies used to prevent potbound root systems. Root growth was stimulated when plants with a naturally deep root system were grown in containers with a 7.9 height: width ratio, while growth of plants with a shallow root system was severely restricted in those containers (Biran and Eliassaf, 1980). The growth of deep-rooted woody plants also increased when these plants were grown in deeper containers with a height : width ratio of 3.0 vs. shallow containers with a height : width ratio of 0.4 (Keever et al., 1985).
\end{abstract}

Copper compounds applied to the inside of containers or flats inhibits root growth, resulting in a more fibrous root system with a better root distribution within the container (Arnold and Struve, 1989). Studies on various species found increased and decreased growth responses for plants in copper-treated vs. nontreated containers (Arnold and Struve, 1989; Beeson and Newton, 1992; Furuta et al., 1972). Our objectives were to determine whether shoot and root growth of a vigorously growing species, Eucalyptus citriodora Hook., would be better in tall vs. regular-shaped containers with the same volume and whether coating the inside of the container with $\mathrm{CuCO}_{3}$ would reduce root circling and improve root and shoot growth.

Eucalyptus citriodora liners were transplanted on 15 Aug. into plastic 3.7-liter containers of regular (standard no. 1) or tall configuration. Regular containers were $16.0 \mathrm{~cm}$ in diameter and $17.5 \mathrm{~cm}$ tall; the dimensions of the tall ones were 10.0 and $40.0 \mathrm{~cm}$, respectively. The height : width ratio of regular and tall containers were 1.1 and 3.8 , respectively. All containers were filled with 3.0 liters of Univ. of California Mix no. 2 (Baker, 1985). Tall containers were manufactured from polyvinyl chloride pipe cut to the specified height. Nylon screen was fastened to the bottom of the pipe and taped around the outside of the pipe.

Received for publication 10 July 1995 . Accepted for publication 6 Oct. 1995. The cost of publishing this paper was defrayed in part by the payment of page charges. Under postal regulations, this paper therefore must be hereby marked advertisement solely to indicate this fact.
Interior surfaces of half of the tall and regular containers were painted with $100 \mathrm{~g} \mathrm{CuCO}_{3} /$ liter white, exterior latex paint.

Plants were grown in a glasshouse with setpoints of $28 \mathrm{C}$ day/16C night. Irrigation was delivered with individual drip emitters to each pot. Plants were fertilized at each irrigation cycle with Foliage-Pro 9N-3P-6K (Dyna Gro Corp., San Pablo, Calif.) formulation at 100 $\mathrm{mg} \mathrm{N} /$ liter.

Plant height, number of branches, and cumulative length of lateral branches were measured on 10 plants 2, 5, 7, and 11 months after transplanting. Shoot and root dry weight of five plants from each treatment combination were determined 3 and 7 months after transplanting and of 10 plants 11 months after transplanting. At 11 months, the outer surfaces of the rootballs were visually inspected for circling or matting of roots. The experiment was a completely randomized design with 20 replications for the four treatment combinations: tall and regular container configuration and presence or absence of $\mathrm{CuCO}_{3}$. Data were tested by analysis of variance and means comparison for each sampling date.

Plants growing in tall vs. regular containers had 58\% more root dry weight and $39 \%$ more shoot dry weight 3 months after transplanting (Table 1). Of plants growing in tall compared to regular-shaped containers, $58 \%$ and $40 \%$ higher root dry weights were recorded 7 and 11 months after transplanting, but no differences in shoot dry weights were found. For plants growing in tall containers, root : shoot ratios decreased from 0.66 after 3 months to 0.14 after 11 months. For plants

Table 1. Dry weight of Eucalyptus citriodora growing in regular or tall containers for 3, 7, and 11 months after transplanting.

\begin{tabular}{|c|c|c|c|}
\hline $\begin{array}{l}\text { Container } \\
\mathrm{ht}\end{array}$ & $\begin{array}{c}\text { Root dry } \\
\text { wt (g) }\end{array}$ & $\begin{array}{c}\text { Shoot dry } \\
\text { wt (g) }\end{array}$ & $\begin{array}{c}\text { Root : shoot } \\
\text { ratio } \\
\end{array}$ \\
\hline \multicolumn{4}{|c|}{ After 3 months } \\
\hline Tall & $5.4 \mathrm{a}^{\mathrm{z}}$ & $8.3 \mathrm{a}$ & $0.66 \mathrm{a}$ \\
\hline Regular & $3.4 \mathrm{~b}$ & $5.9 \mathrm{~b}$ & $0.58 \mathrm{~b}$ \\
\hline \multicolumn{4}{|c|}{ After 7 months } \\
\hline Tall & $5.5 \mathrm{a}$ & $21.4 \mathrm{a}$ & $0.25 \mathrm{a}$ \\
\hline Regular & $3.5 \mathrm{~b}$ & $17.9 \mathrm{a}$ & $0.19 \mathrm{~b}$ \\
\hline \multicolumn{4}{|c|}{ After 11 months } \\
\hline Tall & $6.8 \mathrm{a}$ & $48.2 \mathrm{a}$ & $0.14 \mathrm{a}$ \\
\hline Regular & $4.9 \mathrm{~b}$ & $48.7 \mathrm{a}$ & $0.10 \mathrm{a}$ \\
\hline
\end{tabular}

${ }^{\mathrm{z}}$ Mean separation within columns at $P \leq 0.05$. growing in regular containers, root : shoot ratios were $12 \%$ and $24 \%$ less after 3 and 7 months (Table 1).

Increased root : shoot ratios in tall containers were due to increased root growth. Similarly, root and shoot growth were stimulated when deep-rooting plants were cultivated in containers with a high height : width ratio (Biran and Eliassaf, 1980; Keever et al., 1985). We attributed more root growth in tall containers to better aeration of the medium. Two containers with different depths filled with the same medium are known to have the same saturated depth, but taller containers have a greater depth of well-aerated medium that is suitable for root growth (Whitcomb, 1988).

Cupric hydoxide had no effect on dry weight, root: shoot ratio, or height. In contrast, Furuta et al. (1972) reported reductions in root and shoot growth of $E$. viminalis Labill. that were grown for 10 weeks in coppernaphthenatetreated containers, mainly due to the absence of roots at the interface of the medium and the container wall. Those plants produced more root mass after they were transplanted into larger, nontreated containers.

Roots were fewer on the sides of rootballs of plants in $\mathrm{CuCO}_{3}$-treated containers than in nontreated containers. More roots grew to the bottom of nontreated containers. Copper treatment reduced, but did not completely eliminate, roots at the bottom of containers.

With this study, we can add another woody species to the list of plants whose root growth can be controlled in $\mathrm{CuCO}_{3}$-treated containers without affecting biomass production. For containers of the same volume, tall ones with height : width ratio of 3.8 produced plants with more roots than regular-shaped containers (standard no. 1) with a height : width ratio of 1.1 , presumably because tall containers have a larger volume of well-drained soil.

\section{Literature Cited}

Arnold, M.A. and D.K. Struve. 1989. Growing green ash and red oak in $\mathrm{CuCO}_{3}$-treated containers increases root regeneration and shoot growth following transplant. J. Amer. Soc. Hort. Sci. 114:402-406.

Baker, K.F. 1985. The U.C. system for producing healthy container-grown plants. Surrey Beatty \& Sons, Chipping Norton, Australia.

Beeson, R.C., Jr., and R. Newton. 1992. Shoot and root response of eighteen southeastern woody landscape species grown in cupric hydroxidetreated containers. J. Environ. Hort. 10:214217.

Biran, I. and A. Eliassaf. 1980. The effect of container shape on the development of roots and canopy of woody plants. Scientia Hort. 12:183193.

Furuta, T., W.C. Jones, W. Humphrey, and T. Mock. 1972. Chemical control of root growth in containers. Calif. Agr. 26:10-11.

Keever, G.J., G.S. Kobb, and R.B. Reed. 1985. Effects of container dimension and volume on growth of three woody ornamentals. HortScience 20:276-278

Whitcomb, C.E. 1988. Plant production in containers. Lacebark Publications, Stillwater, Okla. 